\title{
Doctor-patient communication between obedience and partnership
}

\author{
Comunicarea medic-pacient între supunere şi parteneriat
}

\section{Oana Atomei}

Universitatea „Stefan cel Mare“, Suceava,România

\begin{abstract}
Clinical practice is patient-centered. Communication is the main element on which the physician-patient relationship is based. The social class, gender, age, race, and ethnicity are some social contextual elements that shape the content of physician-patient communication and can become the basis of domination and subordi-nation. The physician always controls the discourse during medical consultation because he has the "power" to direct the conversation to the most relevant aspects from a medical point of view. As he/she acquires more knowledge and understanding about his/her health, the patient has more participatory attitude and behavior and interrupts the doctor by asking questions and demanding explanations. Informed consent facilitates doctor-patient communication and strengthens mutual trust, and new technologies bring in front of the doctor an informed but problematic patient. The doctor-patient partnership is shaped in this context.
\end{abstract}

Keywords: communication, doctor, patient

\section{REZUMAT}

Practica clinică este centrată pe pacient. Comunicarea reprezintă elementul principal pe care se bazează relaţia medicului cu pacientul. Clasa socială, sexul, vârsta, rasa şi etnia sunt câteva elemente din contextul social care modelează conţinutul comunicării medic-pacient şi pot deveni baza dominării şi a subordonării. Medicul controlează întotdeauna discursul medical din timpul consulaţiei pentru că are „puterea“ să direcţioneze conversaţia către aspectele cele mai relevante din punct de vedere medical. Pe măsură ce dobândeşte mai multă cunoaştere şi înţelegere a stării lui de sănătate, pacientul are o atitudine mai participativă şi întrerupe medicul adresându-i întrebări şi cerându-i explicaţii. Consimţământul informat facilitează comunicarea medic-pacient şi consolidează încrederea reciprocă, iar noile tehnologii aduc în faţa medicului un pacient informat, dar problematic. În acest context, se conturează caracterul de parteneriat al relaţiei medic-pacient.

Cuvinte cheie: comunicare, medic, pacient

\section{INTRODUCERE}

Se ştie că medicina este atât ştiință, cât şi artă (1), ştiinţa (şi tehnologia) fiind baza demonstrativă pentru rezolvarea problemelor clinice, iar arta fiind aplicarea cunoştințelor medicale combinate cu intuiţia şi judecata clinică pentru a determina cel mai potrivit diagnostic şi plan de tratament pentru fiecare pacient (2).

Medicina este o profesie care se bazează foarte mult pe narațiune. Comunicarea dintre medic şi pacient joacă un rol important în dezvoltarea unei relații încrezătoare, iar încrederea pacientului în medic este unul dintre cele mai importante aspecte atunci când se corelează cu rezultatul îngrijirii.
Schimbul de informații şi negocierea aşteptărilor măresc aderența pacientului.

\section{CONSULTATIIA MEDICALĂ}

În timpul consultației, pacientul îi spune medicului „povestea“ bolii sale. Acesta, la rândul său, manipulează narațiunea adresând întrebări ale căror răspunsuri se regăsesc în fişa medicală. În general, în discuția medic-pacient există un dezechilibru în schimbul de informații: medicii inițiază cele mai multe întrebări, iar pacienții, când îndrăznesc să adreseze o întrebare, se bâlbâie sau se exprimă incoerent. West sugerează că „medicii se află în relație aproape dumnezeiască cu pacienții lor“"(3). 
Clasa socială, sexul, vârsta, rasa şi etnia sunt câteva elemente din contextul social care modelează conținutul comunicării medic-pacient. Toate pot deveni baza dominării și subordonării. Asimetria socială inerentă în relațiile medic-pacient se resimte în conversații. Medicii de sex masculin întrerup pacienții (în special, pacienții de altă etnie sau rasă) mult mai des decât medicii de sex feminin, care, în schimb, sunt întrerupţi mai des de pacienții de sex masculin (3). Sunt de remarcat reținerea cu care pacienții, indiferent de sex, se exprimă în contextul discursului medical, ceea ce poate fi spus, ceea ce apare în centrul discursului şi ceea ce devine marginal sau nu se spune. Unele societăți percep vârstnicii ca pe nişte persoane cu productivitate şi reproductivitate epuizate. Aceştia nu primesc respectul cuvenit indiferent cui se adresează. Despre rasă şi etnie se poate vorbi în contextul contrastului dintre majoritate şi minoritate. Pacienții folosesc formule de politețe când se adresează medicilor, în timp ce medicii tind să utilizeze prenumele pacienților, în special atunci când aceştia sunt de altă etnie sau rasă (4).

În timpul consultaţiei medicale, pacientul vorbeşte inclusiv despre problemele din viața de familie şi de la locul de muncă şi, în general, este întrerupt din diferite motive: relatarea poate să nu contribuie la stabilirea unui diagnostic, versiunea pacientului poate fi confuză sau inconsecventă, poate dura mai mult timp decât este percepută ca fiind disponibilă sau părți ale relatării pot deveni incomode pentru una sau ambele părți. Circumstanţele în care medicul îl întrerupe (ce, când şi de ce este întrerupt) pot fi destul de importante pentru experiența pacientului. Este clar că tendința de a întrerupe sau redirecționa discursul pacientului în timpul consultației derivă din efortul de a pune un diagnostic. Acele părți din discursul pacientului care nu se încadrează perfect în tiparul unui diagnostic funcționează în discursul medical ca nişte „musafiri nepoftiți“ şi tind să fie eliminate. West interpretează întreruperile şi întrebările frecvente ca modalitate de dominație, prin care medicul controlează conversația (3). Ocazional, fluxul interviului poate fi întrerupt de vocea pacientului atunci când acesta se referă la contextul personal şi social al apariției bolii. Dar, în general, astfel de întreruperi sunt reafirmate de către medici.

Modul în care medicul determină pacientul să-şi prezinte starea de sănătate se presupune că este cea mai importantă aptitudine pe care medicii o dezvoltă în interacțiunea cu pacientul. Concentrarea medicului asupra aspectelor biomedicale poate să împiedice exprimarea deplină a preocupărilor paci- entului. Discursul medicului trebuie direcționat nu numai spre pacient, ci şi spre factorii externi cu care interacționează pacientul, în măsura în care aceştia contribuie pozitiv la ameliorarea sau îndepărtarea bolii.

\section{ROLUL MEDICULUI}

În general, de la începutul interviului, medicul testează ipoteze de diagnostic. Pornind de la câteva elemente, cum ar fi problema inițială a pacientului, sexul, vârsta, vocea şi aspectul fizic, medicul formulează o idee inițială despre problema pacientului. $\mathrm{Cu}$ toate acestea, datele furnizate inițial de către pacient nu sunt suficiente pentru a stabili un diagnostic. De aceea, medicul adresează întrebări specifice pentru a obține mai multe date considerate utile pentru testarea ipotezei iniţiale. În timpul interviului, medicul adaptează dialogul cu întrebări care sunt considerate relevante în obținerea unui diagnostic final şi unic. Întregul interviu, inclusiv examenul clinic care urmează, poate fi definit ca un proces ciclic cu acțiuni de testare a ipotezelor (5).

În paralel cu stabilirea unei relaţii bune cu pacientul, alături de organizarea şi adaptarea conversației, apoi verificarea ipotezelor despre boli şi tratamente, medicul trebuie să asculte cu atenție pacientul, să îi acorde atenția necesară, să ceară pacientului să-şi prezinte preocupările şi să interpreteze toate informațiile, utile sau nu, pe care pacientul le oferă. Rifkin şi Lazris subliniază distincția dintre ,a auzi“" şi ,a asculta“ atunci când se referă la îngrijirea centrată pe pacient şi comunicarea eficientă cu acesta (6).

Cele mai multe reclamații nu au legătură cu competența clinică, ci sunt legate de problemele de comunicare. Un număr mare de pacienți nu înțeleg sau nu îşi amintesc ce le spun medicii despre diagnostic şi tratament. S-a demonstrat că nemulțumirea pacienţilor se datorează în principal incertitudinii şi lipsei de informaţii, explicaţii şi feedback din partea medicului (7). Medicii sunt adesea blamați pentru că nu ascultă preocupările pacienţilor şi sunt deseori criticaţi că nu au suficient timp pentru pacienți. De multe ori, pacienții pleacă fără să pună întrebări cu privire la îndoielile care îi tulbură şi nelămuririle pe care le au.

Un alt element important care contribuie la nemulțumirea pacienților este limbajul folosit de către medici. Este adesea neclar şi conține un jargon medical care nu este pe deplin comprehensibil pentru pacienții care nu posedă cunoştințe medicale. Utilizarea jargonului medical poate provoca neînţelegeri şi poate, de asemenea, să încurajeze pacienţii 
să utilizeze termenii medicali în mod necorespunzător. Pacienții pot crede că au înțeles termenii, însă le-au atribuit înțelesuri generale, nu de specialitate. Prin urmare, de la medici la pacienți, termenii pot căpăta înțelesuri diferite. Explicațiile medicilor şi verificarea a ceea ce au înțeles pacienții sunt esențiale pentru evitarea interpretărilor greşite. Medicii trebuie să furnizeze explicații într-un limbaj complet inteligibil şi să evite utilizarea unor cuvinte care înspăimântă, cum ar fi „,cancer“, deoarece ar putea produce reacții negative din partea pacienților (8). Scriind despre viața lui ca student, medic şi pacient în ultimii 70 de ani, Bank indică standarde foarte înalte pentru medicul ideal. Printre altele, medicul trebuie să asculte preocupările pacientului în mod intenţionat şi complet şi să dovedească înțelepciune în a şti cum să comunice cu pacientul (1). Studiile arată că medicii care s-au îmbolnăvit sau care au avut prieteni apropiați sau membri ai familiei bolnavi sunt mult mai capabili să înțeleagă impactul psihosocial al bolii unui pacient şi modul în care viața unei persoane se schimbă prin boală (9). Povestea doctorului Awdish, apărută în 2018 în volumul In Shock, îndeamnă medicii să nu vadă fiecare pacient ca pe un diagnostic, ci ca pe o ființă umană (10).

Conversația medic-pacient este mult mai complexă, mai puternică, mai flexibilă şi mult mai iefină decât majoritatea tehnologiilor medicale de astăzi, care, în general, nu fac decât un singur lucru într-un singur mod. Comunicarea eficientă nu trebuie să dureze mult. $\mathrm{Cu}$ atenție deplină şi intensă, câteva minute de conversaţie pot oferi foarte multe informații (4).

$\mathrm{Cu}$ toate acestea, ceea ce se petrece în timpul consultaţiei medicale este complex, dinamic şi adesea imprevizibil: toate interacțiunile medic-pacient sunt de obicei influențate de aşteptările ambelor părți (11). Nu există medici şi pacienți standard. Ceea ce poate fi util sau acceptat de un pacient poate să nu fie potrivit pentru altul.

\section{PACIENTUL}

Pacientul este o ființă vie cu corp şi minte şi membru al unei familii, al unei comunități şi al unei societăți. Când are o problemă de sănătate, pacientul apelează la serviciile unui medic. Când medicii adresează întrebări, pacienții încep să descrie problema şi pot încărca discursul cu informații inutile în acel context şi cu preocupări personale care sunt considerate de ei foarte importante. Informațiile suplimentare cărora pacienții le acordă deosebită importanță pot să nu fie potrivite pentru medicii care au ,puterea“ de a direcționa conversația către aspectele cele mai relevante din punct de vedere medical. $\mathrm{Cu}$ toate acestea, o mare influență asupra succesului tratamentelor medicale o au cadrul bolii pacienților, experiența lor subiectivă, sensul şi impactul psihologic al bolii, credințele, prioritățile şi preferințele pacientului pentru tratament (12). Prin urmare, faptul că medicii îi ascultă pe pacienți cu atenție facilitează şi încurajează implicarea activă a pacientului în procesul de vindecare.

Atitudinea mai participativă în timpul consultațiilor, prin adresarea de întrebări sau cereri de explicații, o au tinerii în comparație cu vârstnicii şi pacienții cu nivel educațional mai ridicat faţă de pacienții proveniți din medii socio-culturale inferioare (12). Există inegalitate inclusiv între pacienți cu acelaşi nivel educațional. Față de medic, un farmacist este într-o poziție mai bună decât un inginer atunci când vine vorba de înțelegerea tratamentului prescris (13). În ciuda diferențelor de atitudine, acțiunea participativă a pacienților creşte în general în cursul perioadei de boală, pe măsură ce dobândesc mai multă cunoaştere şi înţelegere a stării lor de sănătate.

Pacienții au dreptul să ia decizii privind investigațiile şi tratamentele medicale. Acest drept este consacrat într-o declarație juridică şi etică numită consimțământ informat. Articolul 7 din Declarația de la Lisabona privind drepturile pacientului (2016) prevede, printre altele, ca medicul să furnizeze informații ,într-un mod potrivit culturii pacientului astfel încât pacientul să le poată înțelege " (14). În mod similar, Carta Europeană a Drepturilor Pacientului (2002) prevede dreptul la informare, dreptul la consimțământ şi dreptul la libera alegere (15). Ambele documente subliniază necesitatea utilizării unui limbaj pe care pacienții îl cunosc şi subliniază faptul că informațiile medicale trebuie furnizate într-un mod coerent cu baza lingvistică a pacienților.

\section{SCHIMBAREA DINAMICII ÎN RELATIIA MEDIC-PACIENT}

Înainte de epoca informaticii, cunoştinţele despre medicină aparțineau numai medicului. La începutul anilor 1980, medicii erau văzuţi ca singurii deținători ai informațiilor medicale, iar pacienții ca obiecte pasive a căror singură sarcină era să răspundă la întrebările medicilor, să îi asculte şi să le respecte indicațiile. Din cauza ignoranței şi a analfabetismului larg răspândite în rândul oamenilor şi a dificultăţilor în accesarea informațiilor medicale, pacienții nu şi-au putut formula opiniile personale. 
Prin urmare, pentru orice problemă de sănătate, pacienții mergeau la medic, care era singurul canal care le furniza informații despre starea lor de sănătate. În virtutea cunoştințelor sale de specialitate, medicul a ocupat poziția dominantă, iar pacientul a cooperat (12).

În ultimii ani, pacienții au devenit din ce în ce mai implicaţi în actul medical, creându-se astfel o relaţie de schimb reciproc de idei şi opinii între ei şi medici. Totuşi, medicul joacă rolul de interlocutor activ, informațiile medicale fiind furnizate la discreția lui (16).

Nivelul educaţional al populaţiei şi gradul de conştientizare a sănătăţii au crescut în ultimii 30 de ani, asistența medicală din lumea occidentală a accentuat din ce în ce mai mult autonomia pacientului în luarea deciziilor (2), iar tendința spre medicina preventivă a contribuit la dorința pacienților de a obține cât mai multe cunoştințe medicale. Ca urmare, pacienții îşi asumă mai multă responsabilitate şi participă activ la deciziile legate de sănătate.

Informațiile privind sănătatea au devenit mai accesibile. Medicul nu mai este singurul canal de achiziție a informațiilor medicale. În ultimul timp, mass-media oferă constant şi accesibil informații şi sfaturi în domeniul sănătății. Media acoperă progresul în medicină, avertizează publicul despre riscurile pentru sănătate, promovează valoarea grijei de sine etc. În acest fel, diferența de informații dintre medici şi pacienți este inversată şi medicii se simt amenințaţi de faptul că mulți pacienți par să aibă mai multe informații decât ei (16). Cu toate acestea, nimic nu a influențat relația medic-pacient mai bine decât internetul. Asistăm la revoluția $e$ pacient (17). Webul oferă o cantitate nelimitată de informații, inclusiv în domeniul sănătății. În general, accesul la informații medicale creşte numărul de pacienți informați, care adresează medicilor întrebări detaliate şi adesea complexe din dorința de a participa activ la deciziile privind îngrijirea lor (12), iar după vizita medicală, aceştia verifică eficiența tratamentelor sugerate (16). Potrivit studiului Health Online 2013, realizat de Pew Research Center's Internet \& American Life Project (2013), femeile, tinerii şi persoanele cu nivel educațional superior din SUA au fost cei mai activi solicitanți de informații online din domeniul sănătății (18). Internetul oferă posibilitatea ca pacientul să comunice cu experți în domeniul sănătătiii, chiar şi anonim. Mai mult decât atât, datorită caracterului imediat al feedbackului şi a disponibilităţii informațiilor nonstop, pare mai convenabil pentru pacient să caute informații online decât să meargă la medic (16).
Totuşi, internetul oferă şi dezavantaje. Este posibil ca pacienții să nu se adreseze medicilor când apar probleme grave de sănătate (16). Alţi factori relevanți sunt natura variabilă şi nesigură a informațiilor medicale de pe internet, pierderea contactului direct cu medicul (palpare, auscultare) şi percepția pacientului informat ca fiind ,un pacient problematic“ (17). Pentru non-experți, informațiile specializate pot duce la percepții şi înţelegeri greşite cu potențial periculos. Pe de altă parte, în general, primele rezultate furnizate de motoarele de căutare trimit către site-uri care nu sunt specializate. Site-urile instituționale, cum ar fi insp.gov.ro (Institutul Național de Sănătate Publică), apar, de obicei, pe paginile următoare. Aşadar, din grabă, neatenție sau necunoaştere, pacientul riscă să acceseze informații neadecvate şi imprecise (uneori legate de interese comerciale). Medicul îi poate explica pacientului care surse sunt autorizate, credibile şi, mai ales, care informații îi pot fi benefice pentru sănătate.

Un alt factor al schimbării dinamicii în relaţia medic-pacient este evoluția tehnologiei. Alături de numeroasele sale beneficii, aceasta a adus computerul în cabinetul medical. Frankel trasează un triunghi echilateral între pacient, medic şi ecranul calculatorului, care, deşi nu este întotdeauna posibil, poate facilita interacțiunea centrată pe pacient în comunicarea cu medicul (istoric clinic, monitorizare, investigații paraclinice) (19).

\section{CONCLUZII}

De-a lungul timpului, evoluția relației de comunicare medic-pacient a fost marcată de prezența unei linii care delimitează zona cunoaşterii de zona ignoranței. În trecut, deciziile medicului erau acceptate cu obediență, iar zona cunoaşterii avea acces interzis pentru pacient. În timp, atenția a fost îndreptată către educarea pacientului sub îndrumare profesională pentru scoaterea lui din necunoaştere. În zilele noastre, odată cu apariţia noilor tehnologii, în special a internetului, pacientul are acces la informații medicale, unele de specialitate, altele neavizate. Acestea pot crea pacientului falsa impresie că poate deveni propriul său medic. El poate păşi pe o cale greşită, fiind convins că deține adevărul şi ,,puterea“. În acest context, lumea medicală a dezvoltat programe de educare a pacientului inclusiv prin intermediul internetului. $\mathrm{Cu}$ toate acestea, în comunicarea cu pacientul, medicului îi revine obligația să-l atenţioneze şi să discute despre căile de cunoaştere spre care s-a îndreptat şi pe care le-a considerat benefice pentru sănătatea lui. Parteneriatul dintre cei doi este complet dacă pacientul 
adresează întrebări şi discută fără rețineri despre problemele sale de sănătate, iar medicul îl ascultă şi, după stabilirea planului corect de diagnostic şi tratament, îl îndrumă pe calea cea mai potrivită prin care acesta poate să-şi îmbunătățească sănătatea şi calitatea vieții.
Conflict of interest: none declared Financial support: none declared

\section{BIBLIOGRAFIE}

1. Bank A. Searching for the best medicine: the life and times of a doctor and patient. USA: Columbia University, 2013.

2. Gotti M., Salager-Meyer F. Introduction. In Gotti M, Salager-Meyer F. (eds.) Advances in Medical Discourse Analysis: Oral and Written Contexts, Studies in Language and Communication Vol. 45, Bern/ Berlin/Bruxelles/Frankfurt am Main/New York/Oxford/Wien, 2006:45.

3. West C. Routine Complications: Troubles With Talk Between Doctors and Patients. Bloomington: Indiana University Press, 1984.

4. Ofri D. What Patients Say, What Doctors Hear, Boston, Massachusetts: Beacon Press, 2017.

5. Sadegh-Zadeh K. Handbook of Analytic Philosophy of Medicine, Dordrecht: Springer, 2012.

6. Rifkin E., Lazris A. Interpreting Health Benefits and Risks. A Practical Guide to Facilitate Doctor-Patient Communication, Switzerland: Springer International Publishing, 2015.

7. Simpson M., Buckman R., Steward M. et al. Doctor-Patient communication: The Toronto consensus statement. British Medical Journal. 1991;303:1385-1387.

8. Welsby P. Communication Skills in the Medical Interview, Interview for the University of Edinburgh Medical School, 2003. https://meducation. net/resources/29767-Communication-skills

9. Buckley L.M. Talking with Patients about the Personal Impact of Illness. The Doctor's Role. CRC Press, 2016.

10. Awdish R. In Shock. How nearly dying made me a better intensive care doctor. Great Britain: Bantam Press, 2018.

11. Haftel L. Patient-Doctor Communication: The Fundamental Skill of Medical Practice. Medical School University of Michigan, 2007.

12. Myfanwy M. The doctor-patient relationship. In Graham Scambler (ed.) Sociology as applied to medicine. $6^{\text {th }}$ ed. New York: Saunders/ Elsevier, 2008:49-65.

13. Mallia P. The Nature of the Doctor-Patient Relationship. Health Care Principles Through the Phenomenology of Relationships with Patients. Springer, 2013.

14. WMA Declaration of Lisbon on the Rights of the Patient, 2016, https:// www.wma.net/wp-content/uploads/2016/11/Patient-rights-20160118. pdf/

15. European Charter of Patients' Rights, 2002. http://ec.europa.eu/ health/ph_overview/co_operation/mobility/docs/health_services co108_en.pdf.

16. Anderson J., Rainey M., Eysenbach G. The Impact of CyberHealthcare on the Physician-Patient Relationship. Journal of Medical Systems. 2003;27(1):67-83.

17. Akerkar S., Bichile L. Doctor-patient relationship: changing dynamics in the information age. Journal of Postgraduate Medicine. 2004; 50(2):120-122.

18. Pew Research Center's Internet \& American Life Project. Health Online 2013:3-18. http://www.pewinternet.org/files/old-media/Files/ Reports/PIP HealthOnline.pdf

19. Frankel R.M. When It Comes to the Physician-Patient-Computer Relationship, the "Eyes" Have It. In: Papadakos PJ, Bertman S (eds.) Distracted Doctoring. Returning to Patient-Centered Care in the Digital Age. Springer International Publishing AG, 2017:87-99. 